\title{
Diagnostic efficacy of erythrocyte sedimentation rate in horses: an integrative
}

\section{systematic review}

\author{
Eficácia diagnóstica da velocidade de hemossedimentação em equinos: uma revisão sistemática \\ Eficacia diagnóstica de la velocidad de sedimentación globular en caballos: una revisión sistemática
}

\begin{abstract}
Erythrocyte Sedimentation Velocity (ESR) is a simple and routine laboratory investigation method in the veterinary clinic for the evaluation of infectious-inflammatory processes and a general indicator of animal welfare. In a systematic review, we evaluated the surroundings of the sensitivity potential of the ESR in the diagnosis of different pathologies in horses. Therefore, a careful search was carried out in Pubmed, ScienceDirect, Scopus, Web of Science and SciELO databases for randomized clinical trials until 2021, which culminated in the literary review of five studies. We evidenced five breeds of horses evaluated through ESR methodologies that varied between the standard Westergren method or the modified Westergren method, with the use of different anticoagulants, such as: ethylenediamine tetraacetic acid (EDTA), citrate and heparin. The ESR showed diagnostic sensitivity and positive correlation with complementary laboratory parameters, such as: hemoglobin, plasma proteins, leukocyte count and red blood cell count. We also emphasize the need for studies with other races and modulations of stress and pathological conditions, especially covering other nationalities and the peculiarities in which they are inserted.
\end{abstract}

Keywords: Erythrocyte sedimentation; Pathologies; Screening; Hematology.

\section{Resumo}

Velocidade de Hemossedimentação (VHS) é um método de investigação laboratorial simples e rotineiro na clínica veterinária para avaliação de processos infecto-inflamatórios e indicador geral de bem-estar animal. Em uma revisão sistemática avaliamos o entorno do potencial de sensibilidade do VHS no diagnóstico de patologias diversas em equinos. Para tanto, realizou-se uma pesquisa criteriosa nas bases de dados Pubmed, ScienceDirect, Scopus, Web of Science e SciELO por estudos clínicos randomizados até 2021, que culminou na revisão literária de cinco estudos. Evidenciamos cinco raças de equinos avaliadas através de metodologias de VHS que variaram entre método padrão de Westergren ou método de Westergren modificado, com uso de anticoagulantes diversos, tais como: ácido etilenodiamino tetracético (EDTA), citrato e heparina. O VHS apresentou sensibilidade diagnóstica e correlação positiva com parâmetros laboratoriais complementares, tais como: hemoglobina, proteínas plasmáticas, contagem de leucócitos e contagem de glóbulos vermelhos. Ressalta-se ainda a necessidade de estudos com outras raças e modulações das condições de estresse e patológicas, em especial que abranja outras nacionalidades e as peculiaridades em que estão inseridos.

Palavras-chave: Eritrossedimentação; Patologias; Triagem; Hematologia. 


\section{Resumen}

La velocidad de sedimentación globular (VSG) es un método de investigación de laboratorio simple y rutinario en la clínica veterinaria para la evaluación de procesos infecciosos-inflamatorios y un indicador general del bienestar animal. En una revisión sistemática, evaluamos el entorno del potencial de sensibilidad de la VSG en el diagnóstico de diferentes patologías en caballos. Por ello, se realizó una cuidadosa búsqueda en las bases de datos Pubmed, ScienceDirect, Scopus, Web of Science y SciELO de ensayos clínicos aleatorizados hasta 2021, que culminó con la revisión literaria de cinco estudios. Se evidenciaron cinco razas de caballos evaluados a través de metodologías de ESR que variaron entre el método de Westergren estándar o el método de Westergren modificado, con el uso de diferentes anticoagulantes, tales como: ácido etilendiaminotetraacético (EDTA), citrato y heparina. La VSG mostró sensibilidad diagnóstica y correlación positiva con parámetros de laboratorio complementarios, tales como: hemoglobina, proteínas plasmáticas, conteo de leucocitos y conteo de glóbulos rojos. Destacamos también la necesidad de estudios con otras razas y modulaciones de estrés y condiciones patológicas, cubriendo especialmente otras nacionalidades y las peculiaridades en las que se insertan.

Palabras clave: Sedimentación de eritrocitos; Patologías; Clasificación; Hematología.

\section{Introduction}

Erythrocyte Sedimentation Velocity (ESR), also called Globular Sedimentation Velocity (VSR) or just erythrocyte sedimentation rate, corresponds to a simple laboratory investigation method widely used in human and veterinary clinical screening. Primarily described with diagnostic value by Biernacki in 1897 and widespread by Faheus in 1918, the method consists of measuring the speed of separation between erythrocytes and plasma in anticoagulable blood by the addition of compounds with anticoagulant properties. This ESR measurement is performed after a minimum rest of 60 minutes and expressed in millimeters per hour (mm/h) (Soares \& Santos, 2009; Grzybowski \& Sak, 2011; Buck et al., 2011).

After the discovery of HSV, Westergren in 1920 standardized the methodology, and Noltze in 1921 spread its use in horses with infectious anemia (Panisset, 1938). Since then, several studies have proposed the application of ESR in a wide variety of species, races, age groups with different methodologies and diagnostic purposes, which has resulted in several modifications. Namely, ESR methods are currently classified into three types: the Westergren method, described as the gold standard method according to the International Council for Standardization in Haematology (ICSH); and the modified Westergren methods, based on the gold method, but with modifications, such as the Wintrobe method and, finally, alternative methods not based on the Westergren method (Dos Santos et al., 2000; Vennapusa et al., 2011; Kratz et al., 2017).

Although ESR has been the subject of study and speculation in the past about its diagnostic potential in various pathologies, ESR is currently considered a nonspecific method and its use in isolation in diagnostic medicine is limited. However, it remains an indispensable marker of infectious and inflammatory processes or even a general indicator of animal welfare (Plebani \& Piva, 2002; Martins et al., 2007).

In this sense, several disorders of an inflammatory nature, hematological imbalances such as anemia, or alterations in proteins of the coagulation system, such as fibrinogen, affect the degree of erythrocyte aggregation and, therefore, culminate in a change in the sedimentation rate of red blood cells (Lima et al., 2001; Kongros \& Tangvarasittichai, 2019). Thus, ESR can be directly or indirectly influenced by the presence of some factors, which in turn are classified into blood factors (intrinsic) such as plasma viscosity, fibrinogen concentration, concentration, morphology and size of erythrocytes, or technical factors (extrinsic) such as anticoagulants, presence of microclots, temperature, feeding status and time to perform the test (Mahlangu \& Davids, 2008; Hachem et al., 2010).

Due to its quick execution, operational simplicity and low cost, the ESR test continues to be a widely used method in the equine veterinary clinic as a predictor of health status, aid in the diagnosis and monitoring of various clinical conditions. In view of the above, we carried out an integrative systematic around the sensitivity potential of the ESR for the diagnosis of pathologies and as a predictive value of the state of well-being in horses. 


\section{Methodology}

The systematic review was conducted according to PRISMA recommendations for the main items reported in integrative systematic reviews (Page et al., 2021).

\subsection{Search sources}

Five databases were consulted in the search for eligible studies in any language from the beginning until the week of October 15, 2021 (1938-2021), namely: Pubmed, ScienceDirect, Scopus, Web of Science and SciELO. The following descriptors were used: Erythrosedimentation rate, Horses, Equine. Keywords were combined using the Boolean operators AND and OR. The search engine was recognized for each database and combinations of descriptors and their respective synonyms were used.

Two independent reviewers independently examined all titles and abstracts retrieved by searches to identify potentially eligible studies. Any record considered potentially eligible by at least one of the reviewers was retrieved in full and evaluated by both reviewers against the eligibility criteria. A third reviewer resolved any discrepancies.

\subsection{Study selection}

\subsubsection{Inclusion criteria}

Studies were considered eligible for inclusion if they related to cross-cultural adaptation in a specific language, if published as a full manuscript in a peer-reviewed journal, and if they consisted of intervention studies with outcomes related to ESR diagnostic sensitivity by stress induction/ stimulus or pathological condition. Works in English, Spanish and Portuguese were analyzed.

\subsubsection{Exclusion Criteria}

Conference proceedings, case reports, literature review, technical manuals, thesis studies, dissertations and conferences were disregarded. Works that were inaccessible in their entirety were also discarded. The study methodology and relevance of the information based the selection.

After the selection of potentially eligible articles, they were read in their entirety by the evaluators to determine the eligibility of the manuscript and studies lacking relevant data were excluded. The data extracted from the articles for the characterization of the studies included: first author and year of publication, country of study, race, sample number of the population studied, intervention, methodology used in the intervention and anticoagulant, additional tests performed in addition to the ESR (Table 1).

\subsection{Types of Participants}

We opted for studies of horses of a defined breed, and they were not excluded by gender and/or age. Intervention groups should have a minimum of eight participants, with no upper limit on the number of participants per group.

\subsection{Types of interventions}

Assays were only included if participants were required to undergo a stress-inducing intervention such as active training, running, strenuous physical exercise, medication administration, or a pathological condition, and with that, to determine the effects of the intervention through the VHS and complementary exams. Intervention protocols varied between studies, from a point-in-time analysis of days to six months. 


\subsection{Evaluation of study characteristics and data analysis}

Two reviewers independently extracted the following data from the included trials: bibliometric data, sample size, participant characteristics (race, age, sex, health status) and details of interventions, methodologies used in ESR screening, and ESR screening results and complements such as total leukocyte and erythrocyte count, hematocrit, fibrinogen and other plasma proteins. A third reviewer resolved any discrepancies. Table 1 summarizes information about the studies used in the review. Relevant information from the works was analyzed and described through descriptive analysis of the variables.

\section{Results and Discussion}

The initial search in the electronic database identified a total of 1,459 records. Of these, 24 duplicate articles and 1,420 that met the eligibility criteria were excluded from the study. Of the 15 full-text records reviewed, 10 articles were considered ineligible, justified by: lack of information about the VHS methodology $(n=03)$; sample number of participants lower than desired $(\mathrm{n}=02)$; type of study $(\mathrm{n}=01)$; and articles unavailable in full $(\mathrm{n}=04)$. Finally, 05 articles were included for qualitative analysis and eligible for an integrative systematic review (Figure 1 and Table 1).

Figure 1 - Flowchart of the search, selection and inclusion of studies in the systematic review process.

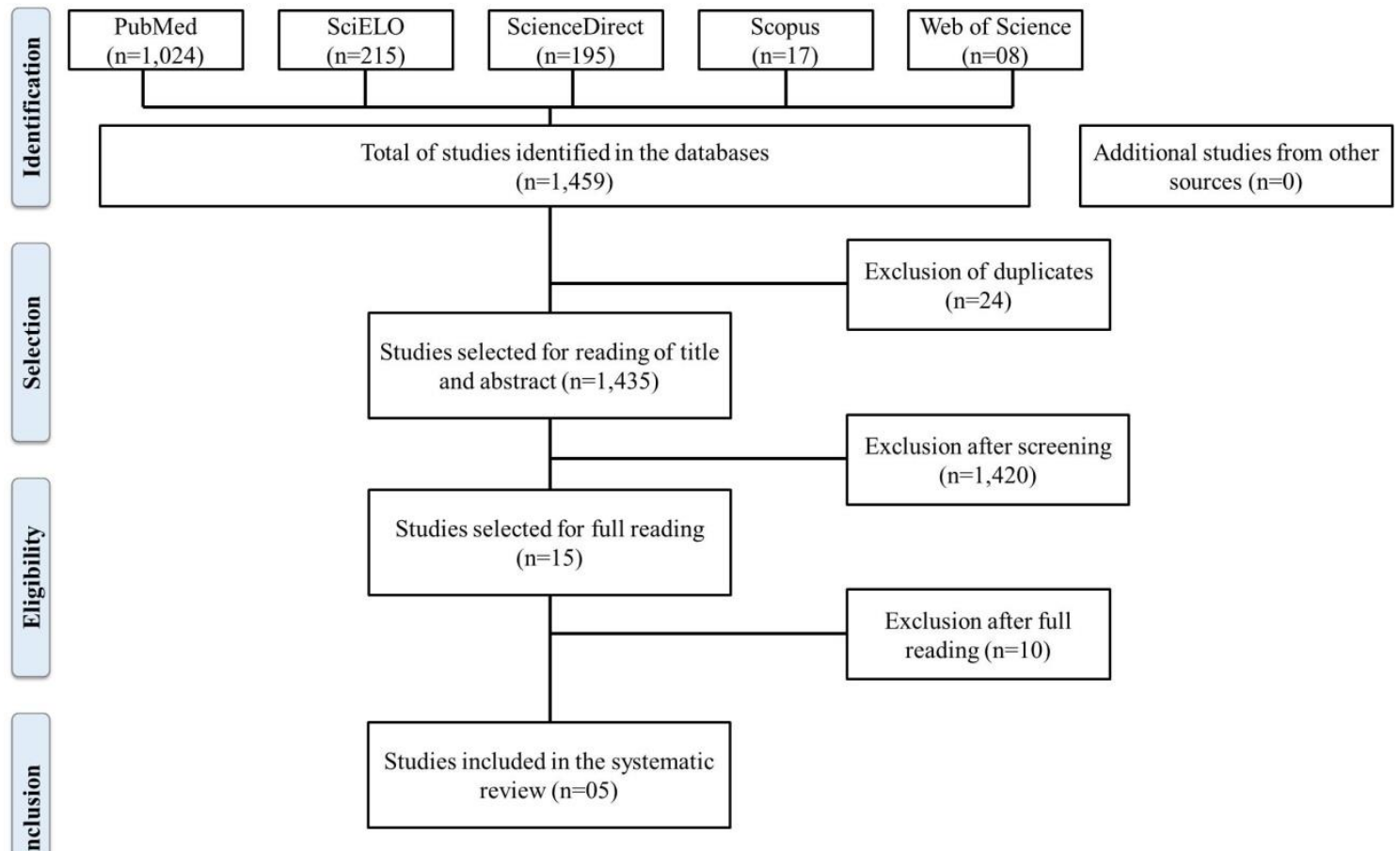

Source: Authors. 
Table 1 - Main aspects of studies on the diagnostic sensitivity of Erythrocyte Sedimentation Velocity (ESR) for horses in chronological order for articles published between 1932 and 2021.

\begin{tabular}{|c|c|c|c|c|c|c|c|}
\hline $\begin{array}{c}\text { Author/ } \\
\text { year }\end{array}$ & Country & Journal & $\begin{array}{l}\text { Sample } \\
\text { (N) }\end{array}$ & Breed & Main aspects & $\begin{array}{l}\text { Methodology/ } \\
\text { anticoagulant }\end{array}$ & Additional analysis \\
\hline Dalton, 1972 & Scotland & $\begin{array}{l}\text { British } \\
\text { Veterinary } \\
\text { Jornal }\end{array}$ & 08 & Pureblood & $\begin{array}{l}\text { Effect of exercise and sedation on } \\
\text { hematimetric parameters in horses. }\end{array}$ & $\begin{array}{l}\text { Wintrobe / } \\
\text { EDTA }\end{array}$ & $\begin{array}{l}\text { HCT, TPP } \\
\end{array}$ \\
\hline Szarska, 1981 & Poland & $\begin{array}{l}\text { Zentralbl } \\
\text { Veterinarmed } \\
\text { A. }\end{array}$ & 10 & Pureblood & $\begin{array}{l}\text { Effect of physical training and running on } \\
\text { hematological and biochemical indices in } \\
\text { horses. }\end{array}$ & Westergren/ Heparin & WBC \\
\hline $\begin{array}{l}\text { Wood; Fedde, } \\
1997\end{array}$ & USA & $\begin{array}{l}\text { Respiration } \\
\text { physiology }\end{array}$ & 24 & $\begin{array}{l}\text { Quarter-mile and } \\
\text { pureblood }\end{array}$ & $\begin{array}{l}\text { Effect of exercise on blood viscoelastic } \\
\text { properties independent of hematocrit in horses. }\end{array}$ & $\begin{array}{l}\text { Westergren / } \\
\text { EDTA }\end{array}$ & $\begin{array}{l}\text { WBC, MCV, HCT, } \\
\text { fibrinogen }\end{array}$ \\
\hline $\begin{array}{l}\text { Gundasheva; } \\
\text { Georgieva, } \\
2015\end{array}$ & Bulgaria & $\begin{array}{l}\text { Veterinarija ir } \\
\text { Zootechnika }\end{array}$ & 15 & Hanoverian & $\begin{array}{l}\text { Effect of physical exercise on systemic and } \\
\text { hematological parameters in horses vaccinated } \\
\text { with EIV and EHV 4/1. }\end{array}$ & $\begin{array}{l}\text { Westergren / } \\
\text { Citrate }\end{array}$ & Fibrionogen, haptoglobin \\
\hline Wuest, 2017 & USA & $\begin{array}{l}\text { Journal of } \\
\text { equine } \\
\text { veterinary } \\
\text { science }\end{array}$ & 12 & $\begin{array}{l}\text { Quarter-mile, hot } \\
\text { blooded and } \\
\text { mustangs }\end{array}$ & $\begin{array}{l}\text { Efficacy of treatment with curcumin, an anti- } \\
\text { inflammatory agent, in inflammatory process } \\
\text { in riding horses through erythrocyte } \\
\text { sedimentation rate. }\end{array}$ & $\begin{array}{l}\text { Westergren / } \\
\text { EDTA }\end{array}$ & $\begin{array}{l}\text { EPF, qPCR, bacteria } \\
\text { culture }\end{array}$ \\
\hline
\end{tabular}

USA: United States of America; EIV: Equine Influenza Virus; EHV 4/1: Equine Herpes Virus 4/1; EDTA: Ethylenediamine tetraacetic acid; HCT: Hematocrit; TPP: Total Plasma Proteins; MCV: Mean Corpuscular Volume; WBC: Total Leukocyte Count; EPF: Fecal Parasitological Examination; qPCR: Real-time polymerase chain reaction. 
Due to the wide time span of the review (1938-2021), the selected studies showed great amplitude in relation to the year of publication, where the oldest article was published in 1972 and the most recent corresponds to a study from 2017. The studies were carried out in the following countries: United States of America $(n=02)$, Bulgaria $(n=01)$, Poland $(n=01)$ and Scotland $(\mathrm{n}=01)$.

According to the eligibility criteria, all articles are experimental studies. As for the sample number of horses in each study, this value ranged from 08 to 24 horses, and totaled 69 animals, of both sexes with varying ages and, as for breeds, the studies were restricted to Thoroughbreds (50.7\%), Quarter Horses (24.6\%), Hanoverians (21.7\%), Mustangs (1.5\%) and Hot Blooded (1.5\%).

Regarding the research objectives, the studies consisted of evaluating changes in the erythrocyte sedimentation velocity values at two moments, or when animals were submitted to two different conditions. Two studies consisted of evaluating the ESR oscillation in horses that were submitted to physical exercise (Szarska, 1981; Wood \& Fedde, 1997), another study, in addition to evaluating the effect of physical exercise, also aimed to evaluate the effect of sedation by acetylpromazine, a preanesthetic phenotyzine tranquilizer, on ESR (Dalton, 1972). The others aimed to evaluate changes in ESR in horses undergoing treatment with Curcumin (Wuest, 2017), and horses vaccinated against equine herpes virus 4/1 (EHV4/1) and equine influenza virus (Gundasheva \& Georgieva, 2015).

As for the methodology used in the evaluation of ESR, $80 \%$ of the articles used the Westergren methodology, which corresponds to the reference method, accepted worldwide and recommended by the International Council for Standardization in Haematology (ICSH), and only 20\% used the Wintrobe method., which is classified as modified Westergren methods, that is, it is a test that is based on the reference method, but has undergone modification, because in this one, a hematocrit microcapillary is used instead of the volumetric pipette as a column to promote erythrocyte sedimentation . Regarding the type of anticoagulant used, when analyzing the articles, a diversification of the type was noticed, with the use of ethylenediamine tetraacetic acid (EDTA) being observed in three studies, followed by Citrate and Heparin, both with only one report.

A variation was observed in the complementary tests performed concomitantly with the ESR, in all studies, however, it was noticed that the determination of hematocrit, fibrinogen dosage, total leukocyte count in two studies, followed by the dosage of total proteins, haptoglobin, blood culture and stool parasitological examination were reported only once together with the ESR.

Surrounding the diagnostic and prognostic sensitivity of the ESR, the studies evaluated in the systematic review showed that the induction of sedation (which in turn induces hypotension) promotes increased erythrocyte sedimentation, and exercise (which causes hypertension and increased cardiac output) promoted decrease in VHS. As for hematocrit and plasma protein concentration, a decrease was observed when the horses were sedated and an increase when the animals were exercised (Dalton, 1972).

Intense training and racing promoted a decrease in erythrocyte sedimentation velocity values in thoroughbred horses. However, the hemoglobin level showed a progressive increase, but statistically insignificant ( $p<0.05)$, and the leukocyte count did not change. Such results guide the potential of sensitivity of the ESR to the adaptive changes of the animals to the physical effort and increase of the oxidative capacity, as also reflected by the increase of the hemoglobin levels (Szarska, 1981).

Similarly, Wood and Fedde (1997) described an increase in hematological parameters such as hematocrit, red blood cell count, leukocyte count, hemoglobin concentration, mean cell volume (MCV) and fibrinogen concentration in all horses evaluated in post-race. As for ESR, a significant post-race decrease was observed, possibly associated with an increase in hematocrit and an increase in yield elastic tension (TEE), which in turn is defined as the elastic stress in which the red blood cells align, the plasma trapped is released and the blood becomes more fluid. Such conditions corroborate with the 
physiological condition evidenced during the race, in which horses need greater blood fluidity and reduction of viscosity in the period of intense physical activity.

Horses vaccinated and submitted to periodic physical exercise had significantly lower ESR when compared to horses not submitted to vaccination and periodic exercise. While in the vaccinated and not periodically exercised group, the ESR was superior when compared with horses not subjected to vaccination and periodic exercise. Regarding the fibrinogen concentration, there was a significant increase compared to horses vaccinated and not periodically exercised. Thus, the ESR showed a negative correlation with the concentration of fibrinogen (Gundasheva \& Georgieva, 2015).

Curcumin treatment had no effect on ESR over the first 13 days of treatment, only on day 14 did the ESR in the curcumin treated horses significantly decrease compared to day 0 , suggesting that it would take at least 14 days for curcumin to evaporate. curcumin could decrease inflammation in riding horses and evidence the potential of ESR as an effective method of prognostication of inflammatory pathologies (Wuest, 2017).

The erythrocyte sedimentation rate was variable, depending on race, health condition and other factors (intrinsic or extrinsic) as it affects erythrocyte deposition more quickly or slowly. Therefore, as already reported in the literature (Lima et al., 2001), it is evident that the erythrocyte sedimentation rate presents a negative correlation in conditions in which there is an increase in cardiac output (blood flow), hemoglobin level, protein level (especially fibrinogen), white blood cell count (leukocytosis), red blood cell count. These results demonstrate that the ESR is a sensitive method to pathophysiological changes in horses, which justifies its use as a laboratory investigation method still widely used in veterinary clinical practice.

\section{Conclusion}

From this review, it was possible to recognize a considerable number of studies involving the use of the erythrocyte sedimentation rate method as a complementary tool for the assessment of the general health status and diagnosis of pathologies in horses. However, most of the studies using ESR in horses are still superficial, which alerts to the need for studies with broader clinical laboratory correlations associated with racial patterns, pathological conditions and specific stress induction, since seasonal and environmental conditions in countries and regions can alter and interfere with erythrocyte sedimentation indices. Furthermore, it is concluded that the ESR, discovered centuries ago, continues to be a highly requested and effective method for what is proposed as a diagnostic screening, despite being considered a non-specific method.

\section{Interest conflicts}

The authors declare no conflict of interest.

\section{Divulgation}

The authors have indicated that they have no affiliations or financial involvement with any organization or entity with a financial interest in or in financial competition with the subject matter or materials discussed in this article.

\section{References}

Buck, A., Velasquez, P. G. \& Düsman, E. (2011). Comparative analysis of differents dilutions for assessment of erythrocyte sedimentation rate (ESR). Arquivos de Ciências da Saúde da UNIPAR, 15(3).

Clinical Laboratory Standards Institute (CLSI). (2011). Procedure for the Erythrocyte Sedimentation Rate (ESR) Test, Approved Standard (5th edn., H2-A5). Villanova, PA.

Dalton, R. G. (1972). The significance of variations with activity and sedation in the haematocrit, plasma protein concentration and erythrocyte sedimentation rate of horses. British Veterinary Journal, 128(9), 439-445. https://doi.org/10.1016/s0007-1935(17)36782-9. 
Dos santos, V. M., Cunha, S. F. C. \& Da cunha, D. F. (2000). Velocidade de sedimentação das hemácias: utilidade e limitações. Revista da Associação Médica Brasileira, 46, 232-236. https://doi.org/10.1590/S0104-42302000000300008.

Grzybowski, A. \& Sak, J. E. B. (2011). (1866-1911): Discoverer of the erythrocyte sedimentation rate. On the 100th anniversary of his death. Clinics in dermatology, 29(6), 697-703. https://doi.org/10.1016/j.clindermatol.2011.08.033.

Gundasheva, D. \& Georgieva, T. (2015). Changes in some acute phase response parameters after physical exercise in horses with booster vaccination against equine herpes virus 4/1 and equine influenza virus. Veterinarija ir Zootechnika, 70(92), 22-28.

Hachem, R. H., Henneberg, R., Nascimento, A. J., Kopp, R. L. \& Silva, P. H. (2010). Undiluted Erythrocyte Sedimentation Rate (ESR): A Trust Full Methodology?. Visão Acadêmica, 11(2), 67-74. http://dx.doi.org/10.5380/acd.v11i2.21370.

Kongros, K., Tangvarasittichai, O., \& Tangvarasittichai, S. (2019). The Rapid Alternative Methods for Erythrocyte Sedimentation Rate Measurement. Journal of Associated Medical Sciences, 52(1), 32-35. https://doi.org/10.14456/jams.2019.6.

Kratz, A., Plebani M., Peng M., Lee, Y. K., McCafferty R. \& Machin, S. J. (2017). ICSH recommendations for modified and alternate methods measuring the erythrocyte sedimentation rate. International journal of laboratory hematology, 39(5), 448-457. https://doi.org/10.1111/ijlh.12693.

Lima, A. O., Soares, J. B., Greco, J. B., Galizzi, J. \& Cançado, J. R. (2001). Métodos de laboratório aplicados à clínica: técnica e interpretaçäo. 8.ed. Rio de Janeiro: Guanabara Koogan, 2013. p.501.

Mahlangu, J. N. \& Davids, M. (2008). Three-way comparison of methods for the measurement of the erythrocyte sedimentation rate. Journal of clinical laboratory analysis, 22(5), 346-352. https://doi.org/10.1002/jcla.20267.

Martins, G. S., Cardoso, A. V \& Marcondes, G. A. (2007). Erythrocyte Sedimentation and Erythrocyte Aggregation Using ESR (Erythrocyte Sedimentation Rate) and UV-Vis Spectrophotometry. Matéria (Rio de Janeiro), 12, 206-214. https://doi.org/10.1590/S1517-70762007000100026.

Page, M. J., McKenzie, J. E., Bossuyt, P. M., Boutron I., Hoffmann, T.C., Mulrow, C.D., Shamseer, L., Tetzlaff, J. M., Akl, E. A., Brennan, S. E., Chou, R., Glanville, J., Grimshaw, J. M., Hróbjartsson, A., Lalu, M. M., Li, T., Loder, E. W., Mayo-Wilson, E., McDonald, S., McGuinness, L. A., Stewart, L. A., Thomas, J., Tricco, A. C., Welch, V. A., Whiting, P. \& Moher, D. (2021). The PRISMA 2020 statement: an updated guideline for reporting systematic reviews. The BMJ, 71, 1-9. https://doi.org/10.1136/bmj.n71.

Panisset, M. (1938). The blood sedimentation test in the diagnosis of equine infectious anaemia. Canadian Journal of Comparative Medicine, $2(1), 3$.

Plebani, M., \& Piva, E. (2002). Erythrocyte sedimentation rate: use of fresh blood for quality control. American journal of clinical pathology, 117(4), 621-626. https://doi.org/10.1309/QB1G-6FRR-DNWX-BKQ9.

Soares, A. L., \& Santos, E. A. (2009). Velocidade de hemossedimentação: comparação entre o método Microtest X (microssedimentação) e o método de referência Westergren. Revista Brasileira de Hematologia e Hemoterapia, 31(1), 47-48. https://doi.org/10.1590/S1516-84842009000100014.

Szarska, E. (1981). An attempt to establish metabolic indices useful in evaluating the training of thoroughbred racehorses. Zentralblatt für Veterinärmedizin Reihe A, 28(9-10), 750-759. https://doi.org/10.1111/j.1439-0442.1981.tb01247.x.

Vennapusa, B., De La Cruz, L., Shah, H., Michalski, V., \& Zhang, Q. Y. (2011). Erythrocyte sedimentation rate (ESR) measured by the Streck ESR-Auto Plus is higher than with the Sediplast Westergren method: a validation study. American journal of clinical pathology, 135(3), 386-390. https://doi.org/10.1309/AJCP48YXBDGTGXEV.

Wood, S. C. \& Fedde, M. R. (1997). Effects of racing and gender on viscoelastic properties of horse blood. Respiration physiology, 107(2), 165-172. https://doi.org/10.1016/s0034-5687(96)02518-2.

Wuest, S., Atkinson, R. L., Bland, S. D. \& Hastings, D. (2017) A Pilot Study on the Effects of Curcumin on Parasites, Inflammation, and Opportunistic Bacteria in Riding Horses. Journal of Equine Veterinary Science, 57, 46-50. https://doi.org/10.1016/j.jevs.2017.06.010. 